\title{
Effects of ontogenetic stage and leaf age on leaf functional traits and the relationships between traits in Pinus koraiensis
}

\author{
Meng Ji ${ }^{1,2} \cdot$ Guangze Jin ${ }^{1,2} \cdot$ Zhili Liu $^{1,2}$
}

Received: 3 December 2020 / Accepted: 19 January 2021 / Published online: 20 March 2021

(C) The Author(s) 2021

\begin{abstract}
Investigating the effects of ontogenetic stage and leaf age on leaf traits is important for understanding the utilization and distribution of resources in the process of plant growth. However, few studies have been conducted to show how traits and trait-trait relationships change across a range of ontogenetic stage and leaf age for evergreen coniferous species. We divided 67 Pinus koraiensis Sieb. et Zucc. of various sizes $(0.3-100 \mathrm{~cm}$ diameter at breast height, DBH) into four ontogenetic stages, i.e., young trees, middle-aged trees, mature trees and over-mature trees, and measured the leaf mass per area (LMA), leaf dry matter content (LDMC), and mass-based leaf nitrogen content (N) and phosphorus content $(\mathrm{P})$ of each leaf age group for each sampled tree. One-way analysis of variance (ANOVA) was used to describe the variation in leaf traits by ontogenetic stage and leaf age. The standardized major axis method was used to explore the effects of ontogenetic stage and leaf age on trait-trait relationships. We found that LMA and LDMC increased significantly and $\mathrm{N}$ and $\mathrm{P}$ decreased significantly
\end{abstract}

Project funding: The work was financially supported by the National Natural Science Foundation of China (No. 31971636), Yong Elite Scientists Sponsorship Program by CAST (2018QNRC001), and the Fundamental Research Fund for the Central Universities (2572018CG03).

The online version is available at http://www.springerlink.com.

Corresponding editor: Yanbo Hu.

Zhili Liu

liuz12093@126.com

1 Center for Ecological Research, Northeast Forestry University, Harbin 150040, People's Republic of China

2 Key Laboratory of Sustainable Forest Ecosystem Management-Ministry of Education, Northeast Forestry University, Harbin 150040, People's Republic of China with increases in the ontogenetic stage and leaf age. Most trait-trait relationships were consistent with the leaf economic spectrum (LES) at a global scale. Among them, leaf $\mathrm{N}$ content and LDMC showed a significant negative correlation, leaf $\mathrm{N}$ and $\mathrm{P}$ contents showed a significant positive correlation, and the absolute value of the slopes of the traittrait relationships showed a gradually increasing trend with an increasing ontogenetic stage. LMA and LDMC showed a significant positive correlation, and the slopes of the traittrait relationships showed a gradually decreasing trend with leaf age. Additionally, there were no significant relationships between leaf $\mathrm{N}$ content and LMA in most groups, which is contrary to the expectation of the LES. Overall, in the early ontogenetic stages and leaf ages, the leaf traits tend to be related to a "low investment-quick returns" resource strategy. In contrast, in the late ontogenetic stages and leaf ages, they tend to be related to a "high investment-slow returns" resource strategy. Our results reflect the optimal allocation of resources in Pinus koraiensis according to its functional needs during tree and leaf ontogeny.

Keywords Leaf age $\cdot$ Leaf dry matter content $\cdot$ Leaf mass per area $\cdot$ Leaf nitrogen content $\cdot$ Leaf phosphorus content . Ontogenetic stage $\cdot$ Pinus koraiensis

\section{Introduction}

Trees, as long-lived organisms, increase in size and structural complexity during ontogeny. Increasing tree age may result in changes in leaf mechanical strength, hormonal regulation, vegetative/reproductive allocation, the ability to absorb nutrients, and adaptation to environmental conditions, all of which may induce associated changes in tree structure and function (Thomas 2011; Martin and Thomas 
2013; Damián et al. 2018; Song et al. 2019). Thus, tree age or ontogenetic stage may be an important cause of trait variation (Steppe et al. 2011; Kuusk et al. 2018). Leaves, as the main organs of photosynthesis in plants, serve as energy converters for primary producers in ecosystems. The growth development and trait characteristics of leaves directly influence the basic behavior and functioning of a plant (Poorter et al. 2008; Falster et al. 2018). Previous studies have suggested that the expression of leaf traits, i.e., leaf thickness, leaf mass per area (LMA), mass-based leaf nitrogen $(\mathrm{N})$ content, and phosphorus (P) content, may vary by ontogenetic stage (England and Attiwill 2005; Juárez-López et al. 2008; Palow and Kitajima 2012; Liu et al. 2020;). However, previous studies on functional traits have generally focused on a certain ontogenetic stage (Azuma et al. 2019) or comparisons based on young and mature individuals (i.e., young trees and canopy trees) (Greenwood et al. 2008; Mediavilla and Escudero 2009; Palow and Kitajima 2012; Kuusk et al. 2018), with fewer studies based on all ontogenetic stages. The trait variation in the early and middle stages of ontogeny may differ from that in the later stages of ontogeny (Thomas and Winner 2002; Thomas 2010). Revealing variations in traits throughout ontogenetic stages will advance our understanding of the causes of intraspecific trait variation.

For evergreen coniferous trees with long leaf longevity, resource investment, allocation patterns, and trait characteristics vary with leaf age (Reich et al. 1991; Pantin et al. 2012; Mediavilla et al. 2014; Liu et al. 2020). For example, studies have shown that LMA and leaf dry matter content (LDMC) increase and $\mathrm{N}$ decreases with leaf age (Niinemets and Lukjanova 2003; Niinemets et al. 2006; Han et al. 2008; Liu et al. 2020). Details of the various patterns of leaf functional traits by leaf age are helpful for better understanding the adaptive strategies used by plants to maximize carbongain, which is the basis for explaining the mechanisms that maintain community structure and optimize productivity (Kikuzawa and Lechowicz 2011).

Recently, the study of plant functional traits has not been limited to single or grouped traits, but the interconnections and trade-offs between traits have received more attention (Wright et al. 2004, 2005; Osnas et al. 2013; Cui et al. 2020). The leaf economic spectrum (LES) describes the coordinated variation in leaf structural, chemical and physiological traits over a resource gradient, reflecting the trade-off between cost in leaf structure and resource return time for leaf economic traits (Wright et al. 2004). However, the LES is based on multivariate analyses of cross-species data and does not distinguish interspecific and intraspecific trait-trait relationships. Additionally, the application of the LES is mainly focused on the adaptation of leaf traits to abiotic factors, i.e., precipitation, temperature, elevated $\mathrm{CO}_{2}$ and soil fertility (Wright et al. 2005; Ordoñez et al. 2009; Kikuzawa et al. 2013; Cui et al. 2020;). However, several studies have shown that the plant ontogenetic stages are a nonnegligible factor in the LES (Niinemets 2015; Siefert et al. 2015; He and Yan 2018; He et al. 2019; Liu et al. 2019). Therefore, understanding the connections and trade-offs between functional traits in different ontogenetic stages is essential to improve the predictive ability of the LES.

Pinus koraiensis Sieb. et Zucc. is the keystone species of the zonal climax vegetation (mixed broadleaved-Korean pine (Pinus koraiensis) forest) in northeastern China. Revealing the variation in leaf traits during tree ontogeny and leaf ontogeny is important for understanding plant tradeoff strategies and species coexistence mechanisms. In this study, we collected leaf samples from 67 P. koraiensis trees across a wide range of tree sizes $(0.3-100 \mathrm{~cm}$ diameter at breast height $(\mathrm{DBH}))$. We determined the age of each tree and divided them into four groups, i.e., young trees, middle-aged trees, mature trees and over-mature trees, based on the characteristics of the different ontogenetic stages of P. koraiensis ( $\mathrm{Zu} \mathrm{1987).} \mathrm{We} \mathrm{measured} \mathrm{four} \mathrm{leaf} \mathrm{functional}$ traits, including two leaf morphological traits (i.e., LMA and LDMC) and two leaf chemical traits (i.e., $\mathrm{N}$ and $\mathrm{P}$ ), in the different ontogenetic stages and leaf ages. Our aim was to explore the effects of ontogenetic stage and leaf age on leaf traits and to reveal whether and how ontogenetic stage and leaf age modulates the leaf trait-trait relationships.

\section{Materials and methods}

\section{Study site}

The field work was conducted at the Liangshui National Natural Reserve $\left(47^{\circ} 10^{\prime} 50^{\prime \prime} \mathrm{N}, 128^{\circ} 53^{\prime} 20^{\prime \prime} \mathrm{E}\right)$ in northeastern China. The reserve is the most typical and complete mixed coniferous and broad-leaved forest system in the northern temperate zone remaining in China. The reserve has a total forested area of 1.88 million $\mathrm{m}^{3}$. It is situated $280-707 \mathrm{~m}$ above sea level and has an average slope of $10^{\circ}-15^{\circ}$. The region has a temperate continental monsoon climate regime, characterized by cold, dry winters and warm, wet summers. The mean annual temperature is $-0.3{ }^{\circ} \mathrm{C}$, the mean maximum temperature is $7.5^{\circ} \mathrm{C}$, and the mean minimum temperature is $-6.6{ }^{\circ} \mathrm{C}$. The mean annual precipitation is $676 \mathrm{~mm}$, and the average number of days of precipitation is $120-150 \mathrm{~d}$. The annual snow accumulation period is $130-150 \mathrm{~d}$.

\section{Experimental design}

Here, we aimed to systematically reveal the effects of ontogenetic stage and leaf age on leaf traits and trait-trait relationships. In mid-October 2018, when the elongation of the current-year shoots was complete, we selected $67 P$. 
koraiensis across a wide range of tree sizes $(0.3-100 \mathrm{~cm}$ $\mathrm{DBH}$ ) in the mixed broadleaved-Korean pine forest. There were 2 individuals with $\mathrm{DBH}<1.0 \mathrm{~cm}$ (measured with a Vernier caliper, and base diameter was used instead of $\mathrm{DBH}), 29$ individuals with $1.0 \leq \mathrm{DBH}<30 \mathrm{~cm}$ (the difference in the DBH between the closest individuals was ca. $1 \mathrm{~cm}$ ), and 36 individuals with $30 \leq \mathrm{DBH} \leq 100 \mathrm{~cm}$ (the difference in the DBH between the closest individuals was ca. $2 \mathrm{~cm}$ ). We also measured tree height and tree age based on the relationship between DBH and the age of each sampled P. koraiensis (Hu et al. 2009). Then, we divided the 67 P. koraiensis into four tree age groups, i.e., age group I: young trees (1-80 years), age group II: middle-aged trees (81-140 years), age group III: mature trees (141-200 years), and age group IV: over-mature trees ( $>201$ years) ( $\mathrm{Zu} \mathrm{1987).}$ The basic information for the $P$. koraiensis individuals in the different tree age groups is summarized in Table 1.

One sample branch (containing all leaf age classes) was collected from the south side of the upper one-third of the exposed canopy for each individual by a professional climber. All the sample branches from the 67 individuals were collected within three consecutive days. We determined the needle age class based on the possible presence of polycyclic shoots and the relative darkness and hardness of the leaves (Eimil-Fraga et al. 2015). The current-year leaves were defined as 0 years old. The leaves formed the previous year were the 1-year-old leaves and so on. All the existing leaves of different leaf ages were collected from each sample branch. To prevent the leaves from losing water, the collected sample leaves were immediately sealed in plastic bags and transported to the laboratory for the determination of morphological and chemical traits.

\section{Leaf trait measurements}

Four functional traits, i.e., LMA $\left(\mathrm{g} \mathrm{m}^{-2}\right)$, LDMC $\left(\mathrm{mg} \mathrm{g}^{-1}\right)$, $\mathrm{N}\left(\mathrm{mg} \mathrm{g}^{-1}\right)$, and $\mathrm{P}\left(\mathrm{mg} \mathrm{g}^{-1}\right)$, were determined for each leaf age class. LMA is closely related to investment in leaf construction and is an important indicator reflecting plant ecological strategies (Westoby et al. 2002). LDMC indicates the leaf water content, storage capacity and strategies for distributing nutrients and substances (Hodgson et al. 2011). $\mathrm{N}$ and $\mathrm{P}$ are important elements that affect plant metabolism, energy transmission and ecological processes (Abdala-Roberts et al. 2018; Guo et al. 2020).

We counted the total needle number and measured the average needle length using a ruler $(0.1 \mathrm{~cm})$ and the leaf fresh mass (LFM, g) with an electronic balance $(0.0001 \mathrm{~g})$. The total needle volume was determined by the volume displacement method (Chen et al. 1997) for each leaf age group. The total needle area for each leaf age group was calculated using the equation from Liu et al. (2020). The sample needles were then dried at $65^{\circ} \mathrm{C}$ for $72 \mathrm{~h}$ and weighed to obtain the leaf dry mass (LDM, g). The LMA and LDMC were calculated as:

$\mathrm{LMA}=\mathrm{LDM} / \mathrm{LA}$

$\mathrm{LDMC}=\mathrm{LDM} / \mathrm{LFM}$

The total $\mathrm{N}$ was measured by the indophenol blue colorimetric method and the total $\mathrm{P}$ was measured by the Mo-Sb colorimetric method using AQ2 automatic discontinuous chemical analyzer (SEAL Analytical, Inc., USA) after the dried sample needles had been digested with $\mathrm{H}_{2} \mathrm{SO}_{4}-\mathrm{H}_{2} \mathrm{O}_{2}$.

\section{Statistical analysis}

All the statistical analyses were performed using R-3.2.5 ( $\mathrm{R}$ Core Team 2016). One-way analysis of variance (ANOVA) and least significant difference (LSD) tests were used to test the significant differences in leaf traits among the different tree age groups and leaf ages. The leaf trait values were $\log _{10}$-transformed before analysis because log-transformation approximately normalized the data. The standardized major axis (SMA) estimation method (Warton et al. 2006) was used to calculate the slope and intercept of the growth equation of any two leaf traits in each tree age group and for each leaf age. A likelihood ratio test was used to test the heterogeneity of the regression slope (Warton and Weber 2002). If there was no significant difference in the slopes, a common slope was used. If there was heterogeneity among the groups, multiple post hoc comparisons were performed. We determined the significance of the difference between the slope and 1 . If the slope was significantly different from 1 , it indicated that there was an allometric growth relationship
Table 1 Statistical information for Pinus koraiensis in four tree age groups $($ mean $\pm \mathrm{SE})$. Different letters indicate significant differences between tree age groups $(p<0.05$, Tukey's HSD)

\begin{tabular}{lcrrr}
\hline Tree age group & Tree age (year) & DBH $(\mathrm{cm})$ & Height $(\mathrm{m})$ & $\begin{array}{r}\text { Number of } \\
\text { individuals }\end{array}$ \\
\hline Young trees & $39 \pm 2^{\mathrm{d}}$ & $9.19 \pm 1.19^{\mathrm{d}}$ & $7.37 \pm 0.83^{\mathrm{d}}$ & 15 \\
Middle-aged trees & $119 \pm 2^{\mathrm{c}}$ & $25.89 \pm 1.55^{\mathrm{c}}$ & $17.18 \pm 0.78^{\mathrm{c}}$ & 17 \\
Mature trees & $173 \pm 1^{\mathrm{b}}$ & $51.15 \pm 2.63^{\mathrm{b}}$ & $22.07 \pm 0.67^{\mathrm{b}}$ & 21 \\
Over mature trees & $242 \pm 4^{\mathrm{a}}$ & $80.49 \pm 1.92^{\mathrm{a}}$ & $27.78 \pm 0.42^{\mathrm{a}}$ & 14 \\
\hline
\end{tabular}


between the two variables; if the difference was not significant, it indicated that there was an isometric growth relationship (Warton et al. 2006). The abovementioned data analysis was performed by the 'agricolae' package and 'smatr' package in R software (R Core Team 2016).

\section{Results}

\section{Leaf trait variations}

\section{Variation in leaf traits with ontogenetic stage}

The ontogenetic stage had significant effects on the LMA, LDMC, $\mathrm{N}$ and $\mathrm{P}(p<0.05)$ (Fig. 1$)$. The LMA and LDMC of the young trees were significantly lower than those of the middle-aged trees, mature trees and over-mature trees. The overall trend was that the LMA and LDMC showed an upward trend with increasing ontogenetic stage. However, $\mathrm{N}$ and $\mathrm{P}$ showed a downward trend with increasing ontogenetic stage.
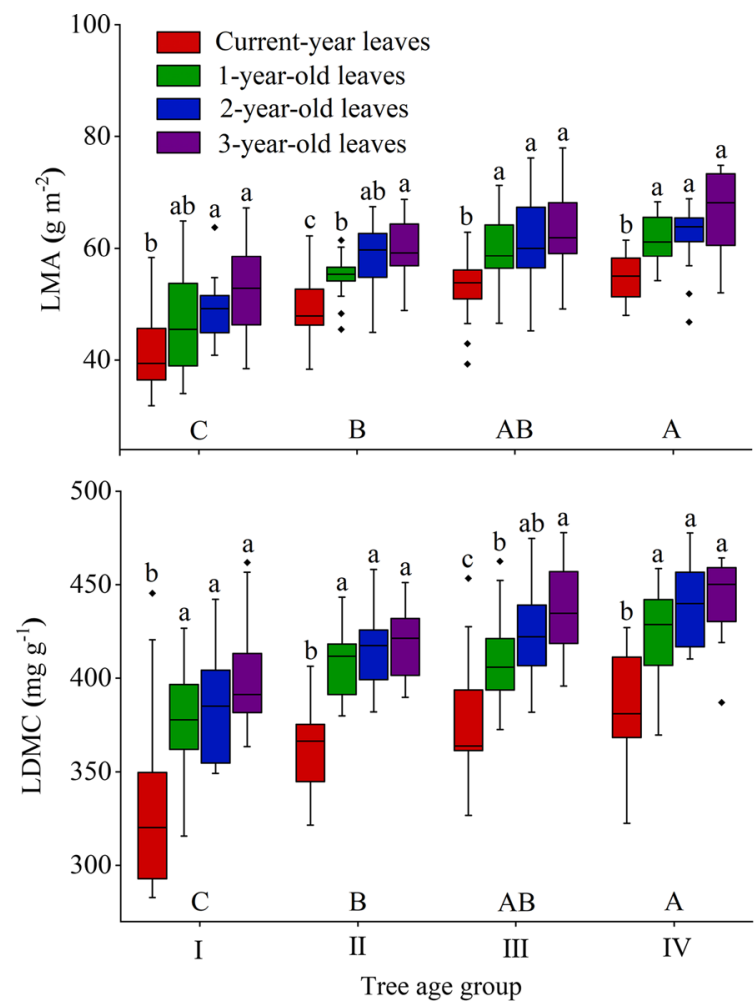

Fig. 1 Leaf mass per area (LMA), leaf dry matter content (LDMC) and mass-based leaf nitrogen content $(\mathrm{N})$ and phosphorus content $(\mathrm{P})$ of Pinus koraiensis in different tree age groups and with different leaf ages. I: young trees; II: middle-aged trees; III: mature trees; IV: overmature trees. Different capital letters below the boxes indicate that the

\section{Variation in leaf traits with leaf age}

There was a significant difference in the leaf traits (LMA, LDMC, $\mathrm{N}$ and $\mathrm{P}$ ) of leaves of different ages in the same tree age group $(p<0.05)$ (Fig. 1). For all tree age groups, the LMA and LDMC of the current-year leaves were significantly smaller than those of the older leaves $(p<0.05)$, but there was less variation in the LMA and LDMC of the 1-year-old, 2-year-old and 3-year-old leaves. Overall, LMA and LDMC showed an upward trend with increasing leaf age. For all tree age groups, $\mathrm{N}$ and $\mathrm{P}$ showed a significant downward trend with leaf age $(p<0.05)$. Among them, the $\mathrm{N}$ of the 1-year-old leaves was the largest, but there was no significant difference between the current-year and 1-yearold leaves, and the $\mathrm{N}$ of the 3 -year-old leaves showed a sharp decline.

\section{Trait-trait relationships}

Variations in trait-trait relationships with ontogenetic stage

$\mathrm{N}$ decreased with LDMC in age group II (middle-aged trees), age group III (mature trees) and age group IV (over-mature
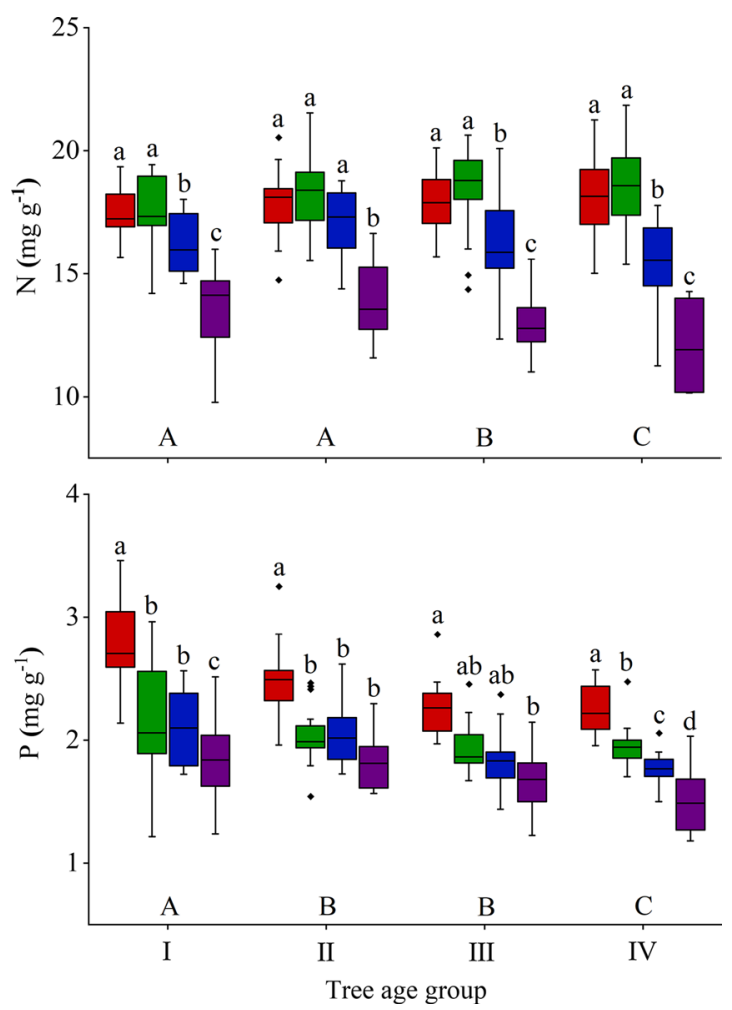

leaf traits were significantly different among the four tree age groups. Different lowercase letters above the boxes indicate that the leaf traits were significantly different among a given leaf age for each tree age group $(p<0.05)$ 
trees), and the slopes of the SMA regression exhibited the following pattern: age group II > age group III > age group IV. The relationship between the regression slopes was significant for age group II and age group IV $(p<0.05)$. The correlation between $\mathrm{N}$ and LDMC was not significant in age group I (young trees).

$\mathrm{N}$ increased with $\mathrm{P}$ in all tree age groups, and the slopes of the SMA regression exhibited the following pattern: age group I < age group II < age group III < age group IV. Additionally, among the regression slopes, there were significant relationships between age group I and the rest of the age groups as well as between age group II and age group IV $(p<0.05)$.

LDMC increased with LMA, and P decreased with LDMC in all tree age groups $(p<0.05)$. $\mathrm{P}$ decreased with LMA in age groups II, III and IV but was unrelated to LMA in age group I ( $p<0.05)$. Additionally, there was no heterogeneity in the SMA slopes for LDMC-LMA, P-LMA, or P-LDMC among the age groups ( $p>0.05)$, and the common slopes were significantly different from $1(p<0.05)$. However, $\mathrm{N}$ showed a decreasing trend with the increase in LMA in age group IV $(p<0.05)$ but was unrelated to LMA in age groups I, II and III $(p>0.05)$.

\section{Variations in trait-trait relationships with leaf age}

LDMC increased with LMA in all the leaf age groups $(p<0.05)$, and the SMA slopes showed a gradual increasing trend. There were significant relationships between the regression slopes of the current-year group and the rest of the leaf age groups $(p<0.05)$. $\mathrm{P}$ decreased with LDMC in the 1-year-old and 3-year-old leaves, and the relationship between the regression slopes of these groups was significant. $\mathrm{N}$ increased with $\mathrm{P}$ in the 2-year-old and 3-year-old leaves, but the relationship between the regression slopes was not significant. P decreased with LMA in the currentyear and 2-year-old leaves, and there was no heterogeneity in the SMA slopes. $\mathrm{N}$ showed an increasing trend with the increase in LMA in the 1-year-old leaves $(p<0.05)$ but was unrelated to LMA in the rest of the leaf age groups.

\section{Discussion}

\section{Leaf trait variations}

Our results demonstrate that ontogenetic stages and leaf age had significant effects on the LMA, LDMC, N and P of $P$. koraiensis (Fig. 1), which may be due to genetic variation in trees and the response of plants to environmental factors, such as light intensity and soil nutrient availability (Scheepens et al. 2010; Wright et al. 2004).
Variation in leaf traits with ontogenetic stage

LMA and LDMC were lower and $\mathrm{N}$ and $\mathrm{P}$ were higher in the early ontogenetic stages, favoring a "low investmentquick returns" resource strategy, while the LMA and LDMC were higher and $\mathrm{N}$ and $\mathrm{P}$ were lower in the later ontogenetic stages, favoring a "high investment-slow returns" resource strategy (Wright et al. 2004; Reich and Cornelissen 2014; Reich and Flores-Moreno 2017).

LMA showed a significant increase with increasing ontogenetic stage, in agreement with the findings of previous studies (Greenwood et al. 2008; Kuusk et al. 2018). A lower LMA means a lower economic investment per leaf area, which contributes to higher resource-use efficiency and growth rates in young trees and may be a genetic ecological strategy in other plants (Wright et al. 2004; Steppe et al. 2011; He and Yan 2018). Additionally, the trees are increasing in size as they age. Tree size may have a greater effect than tree age on leaf structural and physiological traits (Ambrose et al. 2009; Mencuccini et al. 2017). In tall trees, light intensity and water-use efficiency change with the vertical gradient, which in turn leads to changes in leaf physiological characteristics (Ambrose et al. 2009; Coble and Cavaleri 2015; Chin and Sillett 2017). As tree height increases, increased evaporation requirements and restrictions on vertical water transport may limit the physiological function of upper canopy leaves (Woodruff and Meinzer 2011; Ishii et al. 2014), resulting in greater LMA in the leaves of tall trees. Because there is less evaporative surface area per leaf mass, increasing the LMA can effectively reduce the water loss from the leaves of tall trees (Richardson et al. 2000). Many studies have shown that hydraulic limitation is a key factor in the decline in the physiological functioning of trees (Kolb and Stone 2000; Koch et al. 2004). In addition, the greater LMA in the later ontogenetic stages may cause a higher electrical conductivity from the stomata to the chloroplast, which may limit photosynthesis (Niinemets 1997b; Cavaleri et al. 2010).

LMA and LDMC typically indicate a plant's ability to acquire nutrients and water. According to previous studies, LMA is sensitive to changes in light availability, and the higher the light availability, the higher the LMA (Niinemets and Kull 1995; Niinemets et al. 2001; Poorter et al. 2009), but LDMC does not change with the typical light environment (Hodgson et al. 2011). Therefore, compared with LMA, LDMC can better reflect the ability of plants to acquire resources (Roche et al. 2004; Hodgson et al. 2011). In this study, LDMC increased with increasing ontogenetic stage, which is consistent with the findings of some previous studies (Mason and Donovan 2014) but not all (He and Yan 2018). A smaller LDMC means a higher water content and a lower dry matter mass per volume (Wilson et al. 1999; Bill and Thi-Tam 2002; Pérez-Harguindeguy et al. 2013). 
Overall, the smaller LMA and LDMC may reflect the tendency of young trees to allocate fewer resources to developing leaves, minimize investment and maximize returns, and achieve higher growth rates and biomass productivity, which benefits the competitive ability of young trees (Weiher et al. 1999; Saura-Mas and Lloret 2007).

$\mathrm{N}$ is the main component of chlorophyll and photosynthetic enzymes (Ordoñez et al. 2009). Therefore, the decline in $\mathrm{N}$ with ontogeny may reflect the reduction in the photosynthetic rate of leaves, which is consistent with previous studies (Gower et al. 1996; Niinemets 1997b; Merilo et al. 2009). However, $\mathrm{N}$ is also correlated with leaf tissue structure (Harrison et al. 2009; Takashima et al. 2004), and the increased investment in chemical defense substances by tall trees may also lead to an increase in $\mathrm{N}$ (Dominy et al. 2003; Boege 2005; Sendall and Reich 2013). Some studies have also found that $\mathrm{N}$ does not change with tree height or age (Day et al. 2001; Niinemets 2002).

$\mathrm{P}$ showed a significant downward trend with increasing ontogenetic stage; this finding is surprising because it seems to be inconsistent with previous observations (Palow and Kitajima 2012; Song et al. 2019). This may be the result of tree size altering the pattern of $\mathrm{P}$ allocation (Niinemets and Kull 2003). In general, shorter trees tend to allocate more $\mathrm{P}$ to their leaves to improve carbon acquisition efficiency, whereas taller trees may need to allocate more $\mathrm{P}$ to their roots (Niinemets and Kull 2003).

\section{Variation in leaf traits with leaf age}

Changes in leaf functional traits with leaf age can reflect plant life history strategies and the allocation of leaf resources (Niinemets et al. 2006; Han et al. 2008). LMA and LDMC increased and leaf $\mathrm{N}$ and $\mathrm{P}$ contents decreased significantly with increasing leaf age (Fig. 1), which is consistent with the widely observed patterns (Han et al. 2008; Liu et al. 2020). Furthermore, the various patterns of leaf functional traits with leaf age were similar in all the ontogenetic stages. The various patterns occur because, compared to old leaves, young leaves require more resources to optimize organ function and maximize light acclimation (Sultan 2000). Young leaves are at the "low investment-quick returns" end of the LES, which is helpful for seizing more resources as soon as possible and completing growth and reproduction quickly.

The LMA and LDMC of the current-year leaves were significantly lower than those of the older leaves in nearly all the tree age groups (Fig. 1), possibly because of the continuous accumulation and lignification of the cell wall during leaf aging (Mediavilla and Escudero 2003). Additionally, the current-year leaves have the lowest LDMC, which means that the leaves have sufficient water content to support a strong metabolic rate. This result confirms that younger leaves have greater photosynthetic potential than older leaves (Escudero and Mediavilla 2003; Niinemets et al. 2006). Moreover, LMA and LDMC had less variation in the 1-year-old, 2-year-old and 3-year-old leaves. This may be because the structural traits of the older leaves are relatively stable. As trees grow, the longer-lived leaves retained on the older branches will be increasingly covered by the newly extended branches and leaves, so that older leaves usually exist in the shaded part of the canopy. According to previous studies, the light microenvironment can change the effects of needle aging on photosynthesis and coniferous structure (Robakowski and Bielinis 2017). However, some studies have shown that the structure of older needles is only slightly affected by changes in light intensity (Niinemets et al. 2006; Han et al. 2008). In addition, the ability of older leaves to adapt to different light conditions is usually less than that of younger leaves (Brooks et al. 1994; Oguchi et al. 2003). At the same time, needles usually do not change their anatomical structure (except for the secondary growth of vascular tissue) after full expansion in the first growing season (Ewers 1982). Therefore, needle structural traits vary less for older leaves.

In the shade canopy, older leaves may use different biochemical mechanisms to maximize carbon gains. For example, 1-year-old leaves may redistribute nitrogen to thylakoid proteins in a relatively short period of time to adapt to shaded environments (Brooks et al. 1994), which may increase the $\mathrm{N}$ in the leaves. This may be the reason why the $\mathrm{N}$ was higher in the 1-year-old leaves than in the current-year leaves in this study (Fig. 1). This result is in line with the study by Han et al. (2008). However, overall, $\mathrm{N}$ showed a downward trend with increasing leaf age, which is consistent with previous studies (Niinemets et al. 2006). Studies have shown that changes in $\mathrm{N}$ are mainly due to nitrogen dilution, which is attributable to the accumulation of nonstructural carbohydrates and an increase in needle carbon concentration with leaf aging (Niinemets 1997a; Niinemets et al. 2006; Han et al. 2008). It has also been shown that nutrients such as $\mathrm{N}$ and $\mathrm{P}$ can be transferred from senescent leaves and transported to other tissues to promote the growth of young leaves (Nambiar and Fife 1991; Killingbeck 1996;). In this study, there was no significant difference in the $\mathrm{N}$ between the current-year and 1-year-old leaves at different ontogenetic stages (Fig. 1). Even in the middle-aged trees, there was no significant difference in the $\mathrm{N}$ of the current-year, 1-yearold, and 2-year-old leaves. However, the $\mathrm{N}$ content of the 3 -year-old leaves dropped sharply. The most likely reason for this is that the 3 -year-old P. koraiensis leaves are close to the leaf life span, and senescent leaves begin to resorb $\mathrm{N}$, which means that the leaves may be about to fall off. This result agrees with the findings of a study by Escudero and Mediavilla (2003). 


\section{Trait-trait relationships}

The trait-trait relationships of $P$. koraiensis are generally consistent with the LES (Reich and Cornelissen 2014). For example, there were significant positive correlations between LDMC and LMA and between $\mathrm{N}$ and $\mathrm{P}$ and significant negative correlations between $\mathrm{P}$ and LMA, between $\mathrm{N}$ and LDMC, and between $\mathrm{P}$ and LDMC, with allometric growth relationships between the traits (Tables 2, 3 and Figs. 2, 3). Contrary to the expectation of the LES, leaf $\mathrm{N}$ content was significantly correlated with LMA in this study but only for the over-mature trees and 1-year-old leaves; the traits were negatively correlated for the former group and positively correlated for the latter group. However, there was no significant correlation between these traits for most groups. Niinemets (2015) also found that there was no significant correlation between N and LMA in Quercus ilex. This may be because the availability of forest nutrients in different soils and different geographic locations has a greater impact than tree age or leaf age on N (Niinemets 2002; Portsmuth et al. 2005; Portsmuth and Niinemets 2006; Juárez-López et al. 2008), while tree age or leaf age have greater impacts on LMA. In addition, the relationship between $\mathrm{N}$ and LMA may vary among different species. Therefore, the relationship between $\mathrm{N}$ and LMA in the LES varies considerably at the intraspecies level (Siefert et al. 2015).

\section{Variations in trait-trait relationships by ontogenetic stage}

In our study, the SMA slope between N and LDMC and between $\mathrm{N}$ and $\mathrm{P}$ changed in different tree age groups, which is consistent with the findings of previous studies indicating that plant size may affect the patterns of some leaf trait-trait relationships (Liu et al. 2010; Niinemets 2015).

According to previous studies, more than half (up to 75\%) of $\mathrm{N}$ is allocated to chloroplasts for photosynthesis (Warren and Adams 2002, 2006), and only 10-30\% is allocated to the cell wall (Stitt and Schulze 1994), which can indirectly indicate leaf toughness. However, LDMC is generally considered an indicator of leaf toughness (Poorter et al. 2018), and a higher LDMC means that most of the tissue is composed of solid and heavy material. The negative correlation between $\mathrm{N}$ and LDMC reflects the differences of resource allocation and utilization by plants. In addition, the absolute
Table 2 Results of the standardized major axis (SMA) analysis of the correlations among the leaf mass per area (LMA), leaf dry matter content (LDMC) and mass-based leaf nitrogen content $(\mathrm{N})$ and phosphorus content $(\mathrm{P})$ of Pinus koraiensis in four tree age groups

\begin{tabular}{|c|c|c|c|c|c|c|c|c|}
\hline $\mathrm{y}$ & $\mathrm{x}$ & $\begin{array}{l}\text { Tree age } \\
\text { group }\end{array}$ & $\begin{array}{l}\text { Number of } \\
\text { samples }\end{array}$ & $R^{2}$ & Slope & Intercept & $\begin{array}{l}\text { Common } \\
\text { slope test }(P)\end{array}$ & $\begin{array}{l}\text { Heterogene- } \\
\text { ity of slopes } \\
(P)\end{array}$ \\
\hline \multirow[t]{4}{*}{ LDMC } & \multirow[t]{4}{*}{ LMA } & I & 58 & 0.562 & 0.689 & 1.421 & \multirow[t]{4}{*}{0.526} & \multirow[t]{4}{*}{$<0.001$} \\
\hline & & II & 66 & 0.529 & 0.618 & 1.525 & & \\
\hline & & III & 80 & 0.615 & 0.626 & 1.506 & & \\
\hline & & IV & 53 & 0.285 & 0.74 & 1.304 & & \\
\hline \multirow[t]{4}{*}{$\mathrm{N}$} & \multirow[t]{4}{*}{ LMA } & I & 56 & 0.07 & - & - & \multirow[t]{4}{*}{-} & \multirow[t]{4}{*}{$<0.001$} \\
\hline & & II & 66 & 0.043 & - & - & & \\
\hline & & III & 67 & 0.044 & - & - & & \\
\hline & & IV & 49 & 0.168 & -1.666 & 4.18 & & \\
\hline \multirow[t]{4}{*}{$\mathrm{P}$} & \multirow[t]{4}{*}{ LMA } & I & 56 & 0.05 & - & - & \multirow[t]{4}{*}{0.502} & \multirow[t]{4}{*}{$<0.001$} \\
\hline & & II & 66 & 0.12 & -1.296 & 2.575 & & \\
\hline & & III & 67 & 0.404 & -1.189 & 2.383 & & \\
\hline & & IV & 49 & 0.306 & -1.51 & 2.967 & & \\
\hline \multirow[t]{4}{*}{$\mathrm{N}$} & \multirow[t]{4}{*}{ LDMC } & I & 56 & 0.064 & - & - & \multirow[t]{4}{*}{0.001} & \multirow[t]{4}{*}{$<0.001$} \\
\hline & & II & 66 & 0.074 & -1.789 & 5.878 & & \\
\hline & & III & 76 & 0.108 & -1.985 & 6.401 & & \\
\hline & & IV & 49 & 0.251 & -2.21 & 7.004 & & \\
\hline \multirow[t]{4}{*}{$\mathrm{P}$} & \multirow[t]{4}{*}{ LDMC } & I & 57 & 0.137 & -1.849 & 5.092 & \multirow[t]{4}{*}{0.905} & \multirow[t]{4}{*}{$<0.001$} \\
\hline & & II & 66 & 0.167 & -2.097 & 5.772 & & \\
\hline & & III & 67 & 0.571 & -1.964 & 5.405 & & \\
\hline & & IV & 49 & 0.366 & -2.003 & 5.527 & & \\
\hline \multirow[t]{4}{*}{$\mathrm{N}$} & \multirow[t]{4}{*}{$\mathrm{P}$} & I & 57 & 0.407 & 0.593 & 1.009 & \multirow[t]{4}{*}{$<0.001$} & \multirow[t]{4}{*}{$<0.001$} \\
\hline & & II & 66 & 0.18 & 0.853 & 0.952 & & \\
\hline & & III & 67 & 0.273 & 0.996 & 0.939 & & \\
\hline & & IV & 49 & 0.57 & 1.103 & 0.907 & & \\
\hline
\end{tabular}

I: young trees; II: middle-aged trees; III: mature trees; IV: over-mature trees. $R^{2}$ is the coefficient of determination of the SMA regression, with bold numbers indicating significant relationships $(p<0.05)$ 
Table 3 Results of the standardized major axis (SMA) analysis of the correlation among the leaf mass per area (LMA), leaf dry matter content (LDMC), and mass-based leaf nitrogen content $(\mathrm{N})$ and phosphorus content $(\mathrm{P})$ of Pinus koraiensis at different leaf ages

\begin{tabular}{|c|c|c|c|c|c|c|c|c|}
\hline$y$ & $x$ & Leaf age & $\begin{array}{l}\text { Number of } \\
\text { samples }\end{array}$ & $R^{2}$ & Slope & Intercept & $\begin{array}{l}\text { Common } \\
\text { slope test } \\
(P)\end{array}$ & $\begin{array}{l}\text { Heterogene- } \\
\text { ity of slopes } \\
(P)\end{array}$ \\
\hline \multirow[t]{4}{*}{ LDMC } & \multirow[t]{4}{*}{ LMA } & 0 & 67 & 0.61 & 0.670 & 1.427 & \multirow[t]{4}{*}{0.003} & \multirow[t]{4}{*}{$<0.001$} \\
\hline & & 1 & 67 & 0.524 & 0.455 & 1.814 & & \\
\hline & & 2 & 67 & 0.627 & 0.499 & 1.741 & & \\
\hline & & 3 & 56 & 0.342 & 0.459 & 1.811 & & \\
\hline \multirow[t]{4}{*}{$\mathrm{N}$} & \multirow[t]{4}{*}{ LMA } & 0 & 67 & 0.032 & - & - & \multirow[t]{4}{*}{-} & \multirow[t]{4}{*}{$<0.001$} \\
\hline & & 1 & 67 & 0.146 & 0.571 & 0.265 & & \\
\hline & & 2 & 67 & 0.003 & - & - & & \\
\hline & & 3 & 47 & 0.025 & - & - & & \\
\hline \multirow[t]{4}{*}{$\mathrm{P}$} & \multirow[t]{4}{*}{ LMA } & 0 & 64 & 0.265 & -0.832 & 1.789 & \multirow[t]{4}{*}{0.219} & \multirow[t]{4}{*}{0.205} \\
\hline & & 1 & 64 & 0.103 & - & - & & \\
\hline & & 2 & 64 & 0.068 & -0.904 & 1.871 & & \\
\hline & & 3 & 47 & 0.061 & - & - & & \\
\hline \multirow[t]{4}{*}{$\mathrm{N}$} & \multirow[t]{4}{*}{ LDMC } & 0 & 67 & $<0.001$ & - & - & \multirow[t]{4}{*}{-} & \multirow[t]{4}{*}{-} \\
\hline & & 1 & 67 & 0.012 & - & - & & \\
\hline & & 2 & 67 & 0.026 & - & - & & \\
\hline & & 3 & 47 & 0.022 & - & - & & \\
\hline \multirow[t]{4}{*}{$\mathrm{P}$} & \multirow[t]{4}{*}{ LDMC } & 0 & 64 & 0.191 & -1.276 & 3.646 & \multirow[t]{4}{*}{0.001} & \multirow[t]{4}{*}{$<0.001$} \\
\hline & & 1 & 64 & 0.036 & - & - & & \\
\hline & & 2 & 64 & 0.149 & -1.807 & 5.011 & & \\
\hline & & 3 & 47 & 0.011 & - & - & & \\
\hline \multirow[t]{4}{*}{$\mathrm{N}$} & \multirow[t]{4}{*}{$\mathrm{P}$} & 0 & 64 & $<0.001$ & - & - & \multirow[t]{4}{*}{0.043} & \multirow[t]{4}{*}{$<0.001$} \\
\hline & & 1 & 64 & 0.053 & - & - & & \\
\hline & & 2 & 64 & 0.173 & 0.827 & 0.979 & & \\
\hline & & 3 & 47 & 0.301 & 0.783 & 0.939 & & \\
\hline
\end{tabular}

The leaf ages of 0,1, 2 and 3 represent current-year leaves, 1-year-old leaves, 2-year-old leaves and 3-yearold leaves, respectively. $R^{2}$ is the coefficient of determination of the SMA regression, with bold numbers indicating significant relationships $(p<0.05)$ values of the slopes of $\mathrm{N}$ and LDMC significantly increased with ontogenetic stage. This may be because the leaves of the later ontogenetic stages are exposed to higher light availability than the leaves of the early ontogenetic stages. Takashima et al. (2004) showed that oak plants grown under low light conditions (30\% natural light) had higher chlorophyll content than those grown under high light conditions ( $90 \%$ natural light). Therefore, the leaves of the later ontogenetic stages have lower $\mathrm{N}$ and chlorophyll contents.

The significant positive correlation between $\mathrm{N}$ and $\mathrm{P}$ indicates that these elements exert a synergistic action to enhance the photosynthetic capacity of plants (Osaki et al. 1993). However, the slopes of the N-P relationships were steeper (more positive) with increasing ontogenetic stage in this study (Table 2 and Fig. 2), which reflects the difference in $\mathrm{N}$ and $\mathrm{P}$ utilization strategies during the ontogenetic stages of $P$. koraiensis. Liu et al. (2010) showed that $\mathrm{P}$ may be very limited in large trees rather than in small trees. However, light availability is greater for larger trees, and the leaves need more chlorophyll for photosynthesis to maintain growth in adulthood (Savage et al. 2016). Furthermore, tree growth requires more $\mathrm{N}$, which is used in mechanical support structures (Dean 2004).

\section{Variations in trait-trait relationships with leaf age}

Together, LMA and LDMC can indicate the growth strategies of plants in different ontogenetic stages. In this study, there were positive correlations between LDMC and LMA for the four leaf age groups; this is consistent with the results of previous studies of plants at different ontogenetic stages (Tables 2, 3 and Figs. 2, 3). However, with increasing leaf age, the SMA slopes of the LMA-LDMC relationship gradually flattened (the absolute value of the slope decreased). Among them, the slopes of the LMA-LDMC relationship between the leaves of the current year and those of the other age classes were significantly different. However, there were no significant differences in the slopes of the 1-year-old, 2-year-old or 3-year-old leaves, which indicated that the LDMC increased more with increasing LMA in the current-year leaves than in the previous-year leaves. This is possibly because the response 

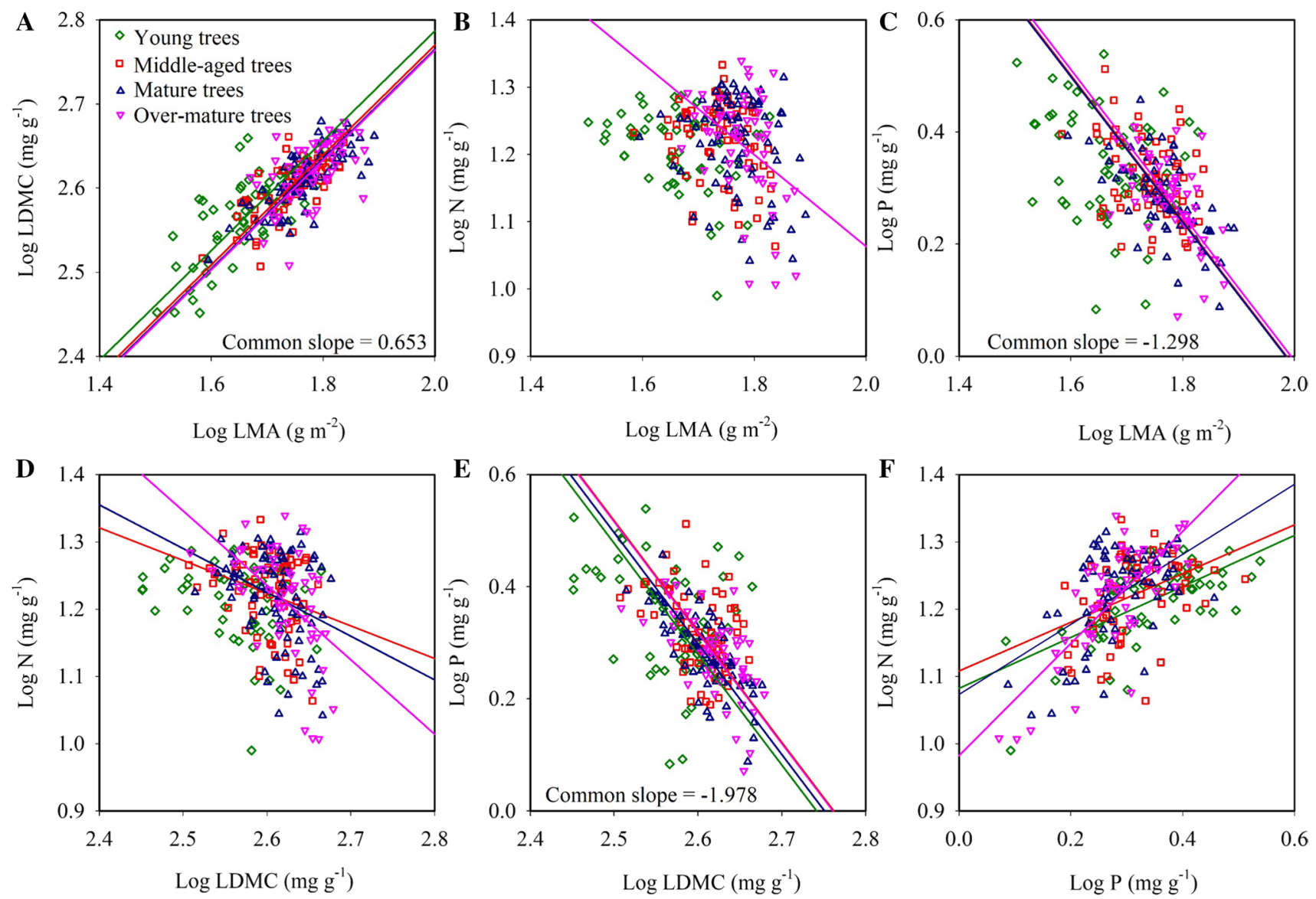

Fig. 2 Standardized major axis (SMA) relationships between the leaf mass per area (LMA) and leaf dry matter content (LDMC) (a), LMA and mass-based leaf nitrogen content $(\mathrm{N})(\mathbf{b})$, LMA and mass-based leaf phosphorus content (P) (c), LDMC and N (d), LDMC and P (e) and $\mathrm{N}$ and $\mathrm{P}$ (f) of Pinus koraiensis in four tree age groups. If there was no significant difference in the slopes of the regression lines, the common slope regression lines are shown. A line is not shown if there was not a significant correlation between the leaf traits sensitivity between LMA and LDMC decreased with the accumulation of dry matter over the leaf life history.

Trait correlation is conducive to determining functional trade-offs and plant strategies; one functional trait can be used to infer another functional trait. Peng et al. (2018) constructed a model for estimating the specific leaf area based on LDMC and further separated the model by using the leaf age as the difference factor; the authors found that leaf age had an effect on the model, with older leaves having a lower model fit. This could be because changes in LDMC maintain a certain degree of relative independence (Garnier et al. 2001). In addition, in this study, $\mathrm{N}$ and LMA, P and LMA, N and LDMC, P and LDMC, and N and $\mathrm{P}$ were either significantly correlated in only a few leaf age classes or not correlated in any of the leaf age classes. This is probably because the structural traits (LMA and LDMC) and chemical traits ( $\mathrm{N}$ and $\mathrm{P}$ ) have different strategies for adapting to changes in leaf aging (Escudero and Mediavilla 2003; Niinemets et al. 2006).

\section{Conclusion}

In our study, ontogenetic stage and leaf age had positive effects on LMA and LDMC and negative effects on N and P, providing evidence that traits are affected by genetic variation and the response of plants to environmental factors. Our results also confirmed that most trait-trait relationships were consistent with the global leaf economic spectrum (LES). However, there were no significant relationships between $\mathrm{N}$ and LMA in most groups, which was contrary to the expectation of the LES. In addition, the absolute values of the slopes of the N-LDMC relationship and N-P relationship showed gradually increasing trends with ontogenetic stage, which suggests that the various patterns of some leaf trait-trait relationships could be modulated by ontogenetic stages. The absolute value of the slope of the LDMC-LMA relationship showed a gradually increasing trend with leaf age, but most pairwise-trait relationships were not significant, which suggests that leaf aging has different effects on 

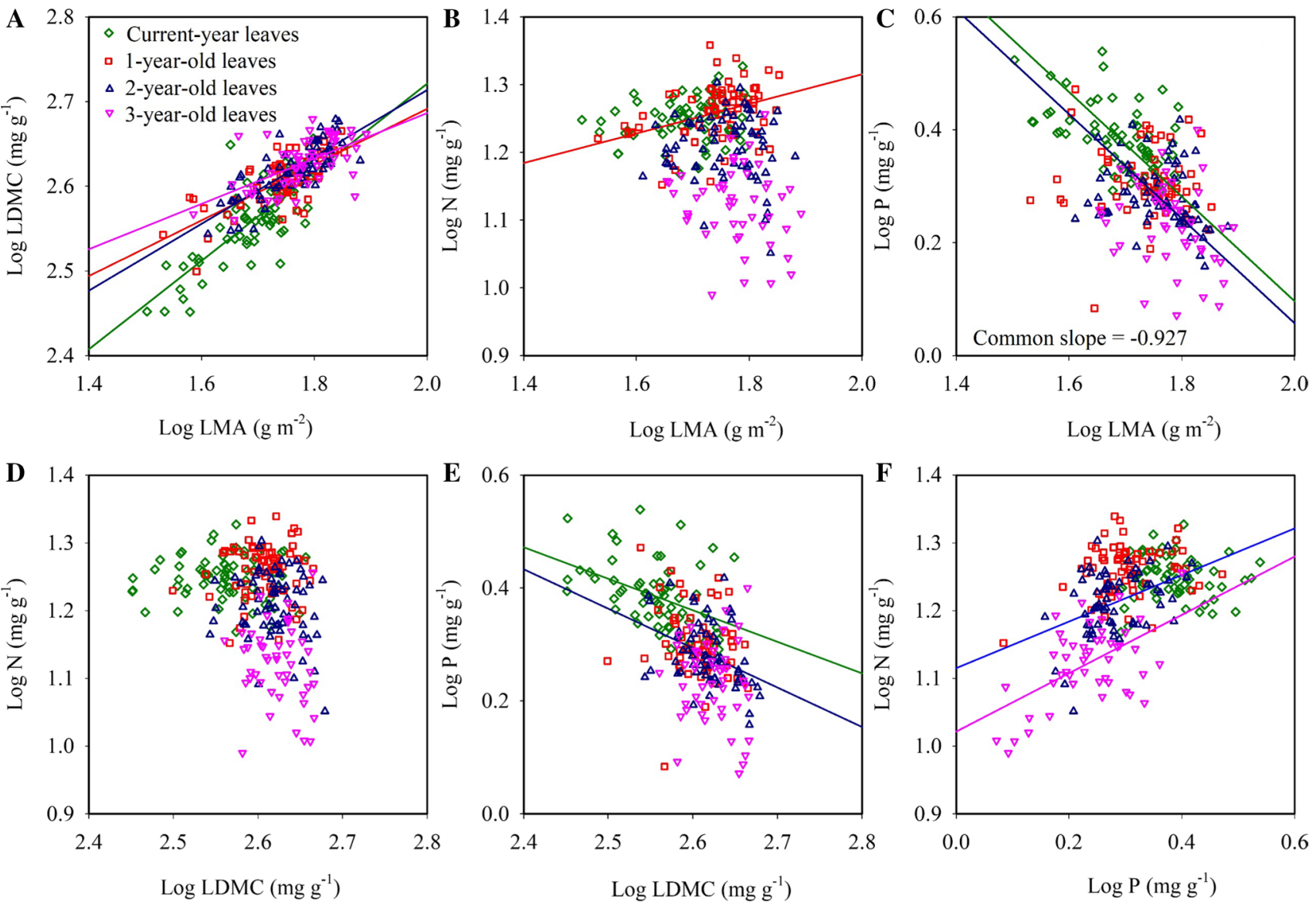

Fig. 3 Standardized major axis (SMA) relationships between the leaf mass per area (LMA) and leaf dry matter content (LDMC) (a), LMA and mass-based leaf nitrogen content $(\mathrm{N})(\mathbf{b})$, LMA and mass-based leaf phosphorus content (P) (c), LDMC and N (d), LDMC and P (e)

structural and chemical traits. Our study provides direct evidence for the coordination of LES traits within species and provides novel insights into understanding the LES at the intraspecific level.

Open Access This article is licensed under a Creative Commons Attribution 4.0 International License, which permits use, sharing, adaptation, distribution and reproduction in any medium or format, as long as you give appropriate credit to the original author(s) and the source, provide a link to the Creative Commons licence, and indicate if changes were made. The images or other third party material in this article are included in the article's Creative Commons licence, unless indicated otherwise in a credit line to the material. If material is not included in the article's Creative Commons licence and your intended use is not permitted by statutory regulation or exceeds the permitted use, you will need to obtain permission directly from the copyright holder. To view a copy of this licence, visit http://creativecommons.org/licenses/by/4.0/. and $\mathrm{P}$ and $\mathrm{N}$ (f) of Pinus koraiensis at different leaf ages. If there was no significant difference in the slopes of the regression lines, the common slope regression lines are shown. A line is not shown if the leaf traits were not significantly correlated

\section{References}

Abdala-Roberts L, Covelo F, Parra-Tabla V, Teran J, Mooney KA, Moreira X (2018) Intra-specific latitudinal clines in leaf carbon, nitrogen, and phosphorus and their underlying abiotic correlates in Ruellia Nudiflora. Sci Rep 8:1-8

Ambrose AR, Sillett SC, Dawson TE (2009) Effects of tree height on branch hydraulics, leaf structure and gas exchange in California redwoods. Plant Cell Environ 32:743-757

Azuma W, Ishii HR, Masaki T (2019) Height-related variations of leaf traits reflect strategies for maintaining photosynthetic and hydraulic homeostasis in mature and old Pinus densiflora trees. Oecologia 189:317-328

Bill S, Thi-Tam V (2002) Dry matter content as a measure of dry matter concentration in plants and their parts. New Phytol 153:359-364

Boege K (2005) Herbivore attack in Casearia nitida influenced by plant ontogenetic variation in foliage quality and plant architecture. Oecologia 143:117-125

Brooks JR, Hinckley TM, Sprugel DG (1994) Acclimation responses of mature abies amabilis sun foliage to shading. Oecologia 100:316-324

Cavaleri MA, Oberbauer SF, Clark DB, Clark DA, Ryan MG (2010) Height is more important than light in determining leaf morphology in a tropical forest. Ecology 91:1730-1739 
Chen JM, Rich PM, Gower ST, Norman JM, Plummer S (1997) Leaf area index of boreal forests: theory, techniques, and measurements. J Geophys Res 102:29429-29443

Chin ARO, Sillett SC (2017) Leaf acclimation to light availability supports rapid growth in tall Picea sitchensis trees. Tree Physiol 37:1352-1366

Coble AP, Cavaleri MA (2015) Light acclimation optimizes leaf functional traits despite height-related constraints in a canopy shading experiment. Oecologia 177:1131-1143

Cui E, Weng E, Yan E, Xia J (2020) Robust leaf trait relationships across species under global environmental changes. Nat Commun 11:1-9

Damián X, Fornoni J, Domínguez CA, Boege K, Baltzer J (2018) Ontogenetic changes in the phenotypic integration and modularity of leaf functional traits. Funct Ecol 32:234-246

Day ME, Greenwood MS, White AS (2001) Age-related changes in foliar morphology and physiology in red spruce and their influence on declining photosynthetic rates and productivity with tree age. Tree Physiol 21:1195-1204

Dean TJ (2004) Basal area increment and growth efficiency as functions of canopy dynamics and stem mechanics. Forest Sci 50:106-116

Dominy NJ, Lucas PW, Wright SJ (2003) Mechanics and chemistry of rain forest leaves: canopy and understorey compared. J Exp Bot 54:2007-2014

Eimil-Fraga C, Sánchez-Rodríguez F, Álvarez-Rodríguez E, Rodríguez-Soalleiro R (2015) Relationships between needle traits, needle age and site and stand parameters in Pinus pinaster. Trees 29:1103-1113

England JR, Attiwill PM (2005) Changes in leaf morphology and anatomy with tree age and height in the broadleaved evergreen species. Eucalyptus Regnans F Muell Trees 20:79-90

Escudero A, Mediavilla S (2003) Decline in photosynthetic nitrogen use efficiency with leaf age and nitrogen resorption as determinants of leaf life span. J Ecol 91:880-889

Ewers FW (1982) Secondary growth in needle leaves of pinus longaeva (bristlecone pine) and other conifers: quantitative data. Am J Bot 69:1552-1559

Falster DS, Duursma RA, Fitzjohn RG (2018) Trajectories: how functional traits influence plant growth and shade tolerance across the life cycle. Proc Natl Acad Sci USA 115:6789-6798

Garnier E, Shipley B, Roumet C, Laurent G (2001) A standardized protocol for the determination of specific leaf area and leaf dry matter content. Funct Ecol 15:688-695

Gower ST, Mcmurtrie RE, Murty D (1996) Aboveground net primary production decline with stand age: potential causes. Trends Ecol Evol 11:378-382

Greenwood MS, Ward MH, Day ME, Adams SL, Bond BJ (2008) Agerelated trends in red spruce foliar plasticity in relation to declining productivity. Tree Physiol 28:225-232

Guo Y, Yan Z, Gheyret G, Zhou G, Xie Z, Tang Z (2020) The community-level scaling relationship between leaf nitrogen and phosphorus changes with plant growth, climate and nutrient limitation. J Ecol 108:1276-1286

Han Q, Kawasaki T, Nakano T, Chiba Y (2008) Leaf-age effects on seasonal variability in photosynthetic parameters and its relationships with leaf mass per area and leaf nitrogen concentration within a Pinus densiflora crown. Tree Physiol 28:551-558

Harrison MT, Edwards EJ, Farquhar GD, Nicotra AB, Evans JR (2009) Nitrogen in cell walls of sclerophyllous leaves accounts for little of the variation in photosynthetic nitrogen-use efficiency. Plant Cell Environ 32:259-270

He D, Yan ER (2018) Size-dependent variations in individual traits and trait scaling relationships within a shade-tolerant evergreen tree species. Am J Bot 105:1165-1174
He YY, Guo SL, Wang Z (2019) Research progress of trade-off relationships of plant functional traits. Chin J Plant Ecol 43:1021-1035

Hodgson JG, Montserrat-Marti G, Charles M, Jones G, Wilson P, Shipley B, Sharafi M, Cerabolini BE, Cornelissen JH, Band SR, Bogard A, Castro-Diez P, Guerrero-Campo J, Palmer C, PerezRontome MC, Carter G, Hynd A, Romo-Diez A, de Torres EL, Royo Pla F (2011) Is leaf dry matter content a better predictor of soil fertility than specific leaf area? Ann Bot 108:1337-1345

Hu YY, Kang XG, Zhao JH (2009) Variable relationship between tree age and diameter at breast height for natural forests in Changbai Mountains. J Northeast For Univ 37:38-42

Ishii HR, Azuma W, Kuroda K, Sillett SC, Watling J (2014) Pushing the limits to tree height: could foliar water storage compensate for hydraulic constraints in Sequoia sempervirens? Funct Ecol 28:1087-1093

Juárez-López FJ, Escudero A, Mediavilla S (2008) Ontogenetic changes in stomatal and biochemical limitations to photosynthesis of two co-occurring Mediterranean oaks differing in leaf life span. Tree Physiol 28:367-374

Kikuzawa K, Lechowicz MJ (2011) Ecology of leaf longevity. Springer, Tokyo, pp 67-75

Kikuzawa K, Onoda Y, Wright IJ, Reich PB (2013) Mechanisms underlying global temperature-related patterns in leaf longevity. Global Ecol Biogeogr 22:982-993

Killingbeck KT (1996) Nutrients in senesced leaves: keys to the search for potential resorption and resorption proficiency. Ecology 77:1716-1727

Koch GW, Stillet SC, Jennings GM, Davis SD (2004) The limits to tree height. Nature 428:851-854

Kolb TE, Stone JE (2000) Differences in leaf gas exchange and water relations among species and tree sizes in an Arizona pine-oak forest. Tree Physiol 20:1-12

Kuusk V, Niinemets Ü, Valladares F (2018) A major trade-off between structural and photosynthetic investments operative across plant and needle ages in three Mediterranean pines. Tree Physiol 38:543-557

Liu F, Yang W, Wang Z, Xu Z, Liu H, Zhang M, Liu Y, An S, Sun S (2010) Plant size effects on the relationships among specific leaf area, leaf nutrient content, and photosynthetic capacity in tropical woody species. Acta Oecol 36:149-159

Liu ZL, Jiang F, Li FR, Jin GZ (2019) Coordination of intra and interspecies leaf traits according to leaf phenology and plant age for three temperate broadleaf species with different shade tolerances. For Ecol Manag 434:63-75

Liu ZL, Hikosaka K, Li FR, Jin GZ (2020) Variations in leaf economics spectrum traits for an evergreen coniferous species: tree size dominates over environment factors. Funct Ecol 34:458-467

Martin AR, Thomas SC (2013) Size-dependent changes in leaf and wood chemical traits in two Caribbean rainforest trees. Tree Physiol 33:1338-1153

Mason CM, Donovan LA (2014) Does investment in leaf defenses drive changes in leaf economic strategy? A focus on whole-plant ontogeny. Oecologia 177:1053-1066

Mediavilla S, Escudero A (2003) Leaf life span differs from retention time of biomass and nutrients in the crowns of evergreen species. Funct Ecol 17:541-548

Mediavilla S, Escudero A (2009) Ontogenetic changes in leaf phenology of two co-occurring Mediterranean oaks differing in leaf life span. Ecol Res 24:1083-1090

Mediavilla S, Herranz M, González-Zurdo P, Escudero A (2014) Ontogenetic transition in leaf traits: a new cost associated with the increase in leaf longevity. J Plant Ecol 7:567-575

Mencuccini M, Martínez-Vilalta J, Hamid HA, Korakaki E, Vanderklein D (2007) Evidence for age- and size-mediated controls of tree growth from grafting studies. Tree Physiol 27:463-473 
Merilo E, Tulva I, Räim O, Kükit A, Sellin A, Kull O (2009) Changes in needle nitrogen partitioning and photosynthesis during 80 years of tree ontogeny in Picea abies. Trees 23:951-958

Nambiar EKS, Fife DN (1991) Nutrient retranslocation in temperate conifers. Tree Physiol 9:185-207

Niinemets Ü (1997a) Acclimation to low irradiance in Picea abies: influences of past and present light climate on foliage structure and function. Tree Physiol 17:723-732

Niinemets Ü (1997b) Distribution patterns of foliar carbon and nitrogen as affected by tree dimensions and relative light conditions in the canopy of Picea abies. Trees 11:144-154

Niinemets Ü (2002) Stomatal conductance alone does not explain the decline in foliar photosynthetic rates with increasing tree age and size in Picea abies and Pinus sylvestris. Tree Physiol 22:515-535

Niinemets $\ddot{U}$ (2015) Is there a species spectrum within the world-wide leaf economics spectrum? Major variations in leaf functional traits in the Mediterranean sclerophyll Quercus ilex. New Phytol 205:79-96

Niinemets Ü, Kull O (1995) Effects of light availability and tree size on the architecture of assimilative surface in the canopy of Picea abies: variation in needle morphology. Tree Physiol 15:307-315

Niinemets Ü, Kull K (2003) Leaf structure versus nutrient relationships vary with soil conditions in temperate shrubs and trees. Acta Oecol 24:209-219

Niinemets Ü, Lukjanova A (2003) Needle longevity, shoot growth and branching frequency in relation to site fertility and within-canopy light conditions in Pinus sylvestris. Ann For Sci 60:195-208

Niinemets Ü, Ellsworth DS, Lukjanova A, Tobias M (2001) Site fertility and the morphological and photosynthetic acclimation of Pinus sylvestris needles to light. Tree Physiol 21:1231-1244

Niinemets U, Cescatti A, Rodeghiero M, Tosens T (2006) Complex adjustments of photosynthetic potentials and internal diffusion conductance to current and previous light availabilities and leaf age in Mediterranean evergreen species Quercus ilex. Plant Cell Environ 29:1159-1178

Oguchi R, Hikosaka K, Hirose T (2003) Does the photosynthetic light acclimation need change in leaf anatomy? Plant Cell Environ 26:505-512

Ordoñez JC, van Bodegom PM, Witte JPM, Wright IJ, Reich PB, Aerts $R$ (2009) A global study of relationships between leaf traits, climate and soil measures of nutrient fertility. Global Ecol Biogeogr 18:137-149

Osaki M, Shinano T, Tadano T (1993) Effect of nitrogen, phosphorus, or potassium deficiency on the accumulation of ribulose-1,5-bisphosphate carboxylase/oxygenase and chlorophyll in several field crops. Soil Sci Plant Nutr 39:417-425

Osnas JL, Lichstein JW, Reich PB, Pacala SW (2013) Global leaf trait relationships: mass, area, and the leaf economics spectrum. Science 340:741-744

Palow DT, Kitajima K (2012) Functional trait divergence of juveniles and adults of nine Inga species with contrasting soil preference in a tropical rain forest. Funct Ecol 26:1144-1152

Pantin F, Simonneau T, Muller B (2012) Coming of leaf age: control of growth by hydraulics and metabolics during leaf ontogeny. New Phytol 196:349-366

Peng X, Yan WD, Wang FQ, Wang GJ, Yu FY, Zhao MF (2018) Specific leaf area estimation model building based on leaf dry matter content of Cunninghamia lanceolata. Chin J Plant Ecol 42:209-219

Pérez-Harguindeguy N, Díaz S, Garnier E, Lavorel E, Poorter H, Jaureguiberry P, Bret-Harte MS, Cornwell WK, Craine JM, Gurvich DE, Urcelay C, Veneklaas EJ, Reich PB, Poorter L, Wright IJ, Ray P, Enrico L, Pausas JG, de Vos AC, Buchmann N, Funes G, Quétier F, Hodgson JG, Thompson K, Morgan HD, ter Steege H, Sack L, Blonder B, Poschlod P, Vaieretti MV, Conti G, Staver AC, Aquino S, Cornelissen JHC (2013) New handbook for standardised measurement of plant functional traits worldwide. Aust J Bot 61:167-234

Poorter L, Wright SJ, Paz H, Ackerly DD, Condit R, Ibarra-Manríquez G, Harms KE, Licona JC, Martínez-Ramos M, Mazer SJ (2008) Are functional traits good predictors of demographic rates? Evidence from five neotropical forests. Ecology 89:1908-1920

Poorter H, Niinemets Ü, Poorter L, Wright IJ, Villar R (2009) Causes and consequences of variation in leaf mass per area (LMA): a meta-analysis. New Phytol 182:565-588

Poorter L, Castilho CV, Schietti J, Oliveira RS, Costa FRC (2018) Can traits predict individual growth performance? A test in a hyperdiverse tropical forest. New Phytol 219:109-121

Portsmuth A, Niinemets Ü (2006) Interacting controls by light availability and nutrient supply on biomass allocation and growth of Betula pendula and B. pubescens seedlings. For Ecol Manag 227:122-134

Portsmuth A, Niinemets Ü, Truus L, Pensa M (2005) Biomass allocation and growth rates in Pinus sylvestris are interactively modified by nitrogen and phosphorus availabilities and by tree size and age. Can J For Res 5:2346-2359

R Core Team (2016) R: a language and environment for statistical computing. R Foundation for Statistical Computing, Vienna, Austria

Reich PB, Cornelissen H (2014) The world-wide 'fast-slow' plant economics spectrum: a traits manifesto. J Ecol 102:275-301

Reich PB, Flores-Moreno H (2017) Peeking beneath the hood of the leaf economics spectrum. New Phytol 214:1395-1397

Reich PB, Walters MB, Ellsworth DS (1991) Leaf age and season influence the relationships between leaf nitrogen, leaf mass per area and photosynthesis in maple and oak trees. Plant Cell Environ 14:251-259

Richardson AD, Berlyn GP, Ashton PMS, Thadani R, Cameron IR (2000) Foliar plasticity of hybrid spruce in relation to crown position and stand age. Can J Bot 78:305-317

Robakowski P, Bielinis E (2017) Needle age dependence of photosynthesis along a light gradient within an Abies alba crown. Acta Physiol Plant 39:83-95

Roche P, Díaz-Burlinson N, Gachet S (2004) Congruency analysis of species ranking based on leaf traits: which traits are the more reliable? Plant Ecol 174:37-48

Saura-Mas S, Lloret F (2007) Leaf and shoot water content and leaf dry matter content of Mediterranean woody species with different post-fire regenerative strategies. Ann Bot 99:545-554

Savage JA, Clearwater MJ, Haines DF, Klein T, Mencuccini M, Sevanto S, Turgeon R, Zhang C (2016) Allocation, stress tolerance and carbon transport in plants: How does phloem physiology affect plant ecology? Plant Cell Environ 39:709-725

Scheepens JF, Frei ES, Stocklin J (2010) Genotypic and environmental variation in specific leaf area in a widespread Alpine plant after transplantation to different altitudes. Oecologia 164:141-150

Sendall KM, Reich PB (2013) Variation in leaf and twig $\mathrm{CO}_{2}$ flux as a function of plant size: a comparison of seedlings, saplings and trees. Tree Physiol 33:713-729

Siefert A, Violle C, Chalmandrier L, Albert CH, Taudiere A, Fajardo A, Aarssen LW, Baraloto C, Carlucci MB, Cianciaruso MV, De LDV, De Bello F, Duarte LD, Fonseca CR, Freschet GT, Gaucherand S, Gross N, Hikosaka K, Jackson B, Jung V, Kamiyama C, Katabuchi M, Kembel SW, Kichenin E, Kraft NJ, Lagerstrom A, Bagousse-Pinguet YL, Li Y, Mason N, Messier J, Nakashizuka T, Overton JM, Peltzer DA, Perez-Ramos IM, Pillar VD, Prentice HC, Richardson S, Sasaki T, Schamp BS, Schob C, Shipley B, Sundqvist M, Sykes MT, Vandewalle M, Wardle DA (2015) A global meta-analysis of the relative extent of intraspecific trait variation in plant communities. Ecol Lett 18:1406-1419 
Song Z, Liu Y, Su H, Hou J (2019) N-P utilization of Acer mono leaves at different life history stages across altitudinal gradients. Ecol Evol 10:1-12

Steppe K, Niinemets Ü, Teskey RO (2011) Tree size- and age-related changes in leaf physiology and their influence on carbon gain. In: Meinzer FC, Lachenbruch B, Dawson TE (eds) Size- and agerelated changes in tree structure and function. Springer, Berlin, pp 235-253

Stitt M, Schulze D (1994) Does Rubisco control the rate of photosynthesis and plant growth? An exercise in molecular ecophysiology. Plant Cell Environ 17:465-487

Sultan SE (2000) Phenotypic plasticity for plant development, function and life history. Trends Plant Sci 5:537-542

Takashima T, Hikosaka K, Hirose T (2004) Photosynthesis or persistence: nitrogen allocation in leaves of evergreen and deciduous Quercus species. Plant Cell Environ 27:1047-1054

Thomas SC (2010) Photosynthetic capacity peaks at intermediate size in temperate deciduous trees. Tree Physiol 30:555-573

Thomas SC (2011) Age-related changes in tree growth and functional biology: the role of reproduction. In: Meinzer FC, Lachenbruch B, Dawson TE (eds) Size- and age-related changes in tree structure and function. Springer, Berlin, pp 33-64

Thomas SC, Winner WE (2002) Photosynthetic differences between saplings and adult trees: an integration of field results by metaanalysis. Tree Physiol 22:117-127

Warren CR, Adams MA (2002) Phosphorus affects growth and partitioning of nitrogen to Rubisco in Pinus pinaster. Tree Physiol 22:11-19

Warren CR, Adams MA (2006) Internal conductance does not scale with photosynthetic capacity: implications for carbon isotope discrimination and the economics of water and nitrogen use in photosynthesis. Plant Cell Environ 29:192-201

Warton DI, Weber NC (2002) Common slope tests for bivariate errorsin-variables models. Biometrical J 44:161-174

Warton DI, Wright IJ, Falster DS, Westoby M (2006) Bivariate line-fitting methods for allometry. Biol Rev Camb Philos Soc $81: 259-291$
Weiher E, van der Werf A, Thompson K, Roderick M, Garnier E, Eriksson O (1999) Challenging theophrastus: a common core list of plant traits for functional ecology. J Veg Sci 10:609-620

Westoby M, Falster DS, Moles AT, Vesk PA, Wright IJ (2002) Plant ecological strategies: some leading dimensions of variation between species. Annu Rev Ecol Syst 33:125-159

Wilson PJ, Thompson K, Hodgson J (1999) Specific leaf area and leaf dry matter content as alternative predictors of plant strategies. New Phytol 143:155-162

Woodruff DR, Meinzer FC (2011) Size-dependent changes in biophysical control of tree growth: The role of turgor. In: Meinzer FC, Lachenbruch B, Dawson TE (eds) Size- and age-related changes in tree structure and function. Springer, Berlin, pp 363-384

Wright IJ, Reich PB, Westoby M, Ackerly DD, Baruch Z, Bongers F, Cavenderbares J, Chapin T, Cornelissen JHC, Diemer M, Flexas J, Garnier E, Groom PK, Gulias J, Hikosaka K, Lamont BB, Lee T, Lee W, Lusk C, Midgley JJ, Navas ML, Niinemets Ü, Oleksyn J, Osada N, Poorter H, Poot P, Prior L, Pyankov VI, Roumet C, Thomas SC, Tjoelker MG, Veneklaas EJ, Villar R (2004) The worldwide leaf economics spectrum. Nature 428:821-827

Wright IJ, Reich PB, Cornelissen JHC, Falster DS, Groom PK, Hikosaka K, Lee W, Lusk CH, Niinemets Ü, Oleksyn J, Osada N, Poorter H, Warton DI, Westoby M (2005) Modulation of leaf economic traits and trait relationships by climate. Global Ecol Biogeogr 14:411-421

$\mathrm{Zu} \mathrm{ZH} \mathrm{(1987)} \mathrm{A} \mathrm{research} \mathrm{of} \mathrm{reasonably} \mathrm{differentiating} \mathrm{the} \mathrm{age} \mathrm{groups}$ of natural korean pine forest. Sci Silva Sin 23:68-75

Publisher's Note Springer Nature remains neutral with regard to jurisdictional claims in published maps and institutional affiliations. 